\title{
Образ советского Дальнего Востока в архитектуре региональных павильонов на сельскохозяйственных выставках в Москве (1923-1954)
}

\author{
К.К.Степанов, НИИТИАГ, Москва
}

С новым этапом в развитии Выставки достижений народного хозяйства, наступившим после 2014 года, и повышенным интересом широкого круга исследователей к теме истории строительства и архитектуры главного выставочного комплекса страны, история развития архитектурно-планировочной композиции павильонов, их архитектурных образов приобретает особенное значение. В статье рассматриваются изменения восприятия Дальнего Востока в контексте советской культуры 1920-х - начала 1950-х годов на примере вариантов павильона дальневосточного региона на крупнейших народнохозяйственных выставках в Москве 1923, 1937, 1939 и 1954 годов. На основе архивных документов, публикаций в печати, проектов и натурных фотографий исследуются особенности архитектурно-планировочной композиции павильонов дальневосточного региона, генезиса их форм и архитектурных образов. Особая атмосфера общенациональных выставок, проходивших в Москве, порождалась не только потребностью демонстрации хозяйственных достижений, но и трансляцией достаточно легко считываемых культурных кодов, формировавших представление населения о различных регионах своей молодой страны. В данном контексте пример павильона, представляющего сложный и самый отдалённый от столицы край, кажется особенно интересным с точки зрения тех изменений, которые произошли и в самом регионе, и в его восприятии архитекторами и художниками, работающими над образом павильона для ВСХВ, ВДНХ и предшествующих им выставок.

Ключевые слова: освоение Дальнего Востока, советские сельскохозяйственные выставки в Москве, проектирование и строительство выставочных павильонов, образ Дальнего Востока в архитектуре.

The Image of the Soviet Far East in the Architecture of Regional Pavilions at Agricultural Exhibitions in Moscow (1923-1954)

\section{K.K.Stepanov, NIITIAG, Moscow}

With a new stage in the development of the Exhibition of Achievements of the National Economy, which began after the year 2014, and the increased interest of a wide range of researchers in the history of architecture of the country's main exhibition complex, specifically in evolution of the architectural and planning composition of the pavilions, their architectural images are of particular importance. The article discusses the changes in the perception of the Russian Far East in the context of the Soviet culture of the 1920-s - early 1950-s, drawing on the versions of the Far Eastern pavilions at the major national exhibitions in Moscow of 1923, 1937, 1939, and 1954. On the basis of archival documents, publications in periodicals, projects, and photographs, the features of the architectural composition of the pavilions, the genesis of their forms, and architectural image are investigated. The special atmosphere of the national exhibitions held in Moscow was generated not only by the need to demonstrate economic achievements but also to represent easily readable cultural codes that formed the national image of the country. The transformation of the image of the Far East through the architecture of its pavilions was one of such cultural messages that influenced the formation of a regional architectural school as well. In this context, the example of a pavilion, representing a complex and the most remote from the capital region, seems especially interesting from the point of view of the changes that have occurred both in the region itself and in its perception by architects and artists working on the image of the Far Eastern pavilion for the All-Union Agricultural Exhibition, Exhibition of Achievements of the National Economy, and previous exhibitions.

Keywords: Russian Far East, Soviet agricultural exhibitions in Moscow, design and construction of exhibition pavilions, regional architectural school.

С началом промышленной революции тема публичной презентации достижений технического прогресса всё больше и больше проникала в сознание людей. Лондонская выставка 1851 года вывела показ национальных достижений во всевозможных областях науки и техники на международный уровень и во многом определила именно этот способ презентации как доминирующий и наиболее авторитетный [1]. В отдельно взятых странах проходили свои выставки, в которых пропаганда государственных успехов занимала также главенствующее положение. Не была исключением и Российская Империя: всероссийские кустарно-промышленные выставки с конца XIX века были важным инструментом в деле популяризации экономических достижений. На «собственном» Востоке России, в столице Приамурского генерал-губернаторства Хабаровске, в честь 300-летия царствования дома Романовых, а также 55-летия образования города в 1913 году прошла своя выставка, целью которой было подвести предварительный итог полувекового присутствия России на берегах Амура [2, с. 81]. На территории почти в 26 гектаров расположились 44 павильона и десятки прочих построек, выполненных местными инженерами-архитекторами. Стилевое разнообразие выставки поражало 
посетителей: главный и крупнейший павильон был выполнен в резном псевдорусском стиле, остальные представляли собой вариации популярного в 1910-е годы стиля модерн с примесью азиатских элементов. Павильон, посвящённый главным городам Приамурского края, разработанный хабаровским гражданским инженером А.К. Левтеевым, также сочетал в себе несколько стилей: в планировке массивного центрального ризалита угадывался классицизм, детали фасада были выполнены в стиле модерн, а в необычной форме куполов вполне можно было уловить азиатские мотивы (рис. 1). В представлении местных архитекторов, которые в подавляющем большинстве были выпускниками столичных императорских инженерных школ [3], Дальний Восток стал своеобразной экспериментальной площадкой, где в условиях самых восточных границ империи, сочетание распространённых в центральных районах архитектурных направлений с некими обобщёнными азиатскими мотивами могло породить особенный региональный стиль.

В результате социальных потрясений Первой мировой и Гражданской войн, появления новой идеологии пропагандистская роль международных, а также всероссийских, затем всесоюзных выставок значительно усилилась. Уже в конце 1922 года на территории будущего парка имени Горького должна была открыться крупная сельскохозяйственная и кустарнопромышленная выставка. Задача «показать основные достижения в области восстановления, укрепления и развития сельского хозяйства на новых началах и под руководством Рабоче-Крестьянской Власти» [4, с. 266] была возложена на ведущих архитекторов страны. В конкурсном проектировании генерального плана выставки принимали участие И.В. Жолтовский, В.А. Щуко, И.А. Фомин и многие другие. Московские и петроградские архитекторы также проектировали зональные и тематические павильоны выставки. Из-за естественных экономических и организационных трудностей «крупнейшее

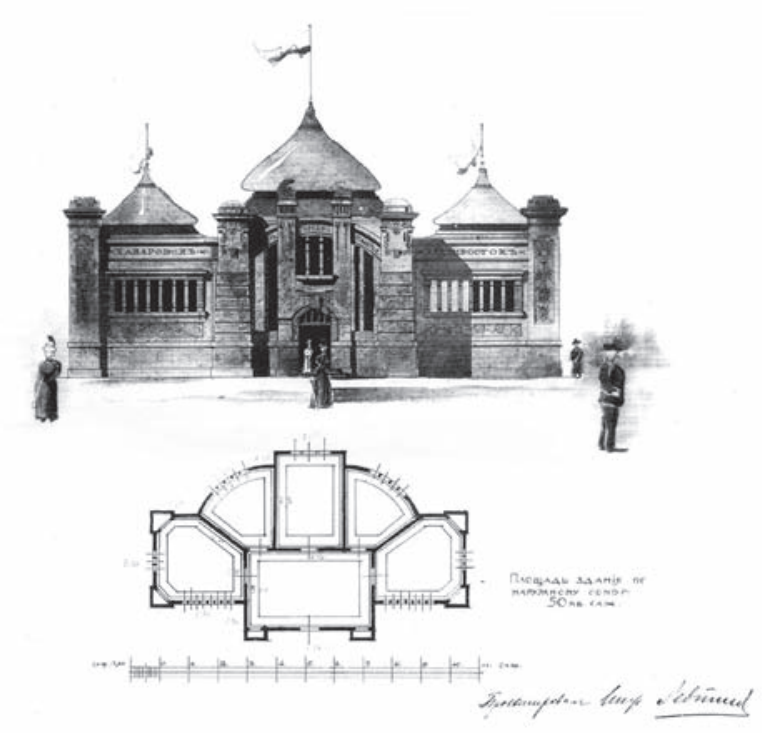

Рис. 1. Павильон городов Приамурья на приамурской выставке в Хабаровске. Архитектор А.К. Левтеев. 1913 год [2, с. 85] событие в области строительства» [5, с. 32] отодвинулось до августа 1923 года, но в результате превзошло все ожидания. Некоторые павильоны, как, например, «Махорка» К.С. Мельникова или входная триумфальная арка авторства И.В. Жолтовского, стали классикой советской архитектуры.

Проектирование павильона Дальнего Востока для этой выставки имело непростую историю. В Чите - в то время столице недавно образованной Дальневосточной области, был организован выставочный комитет, занимавшийся всеми работами, связанными с выставкой: от подбора экспонатов для отправки их в Москву до пропаганды выставки среди местного населения. «Дальвыстком» провёл свой собственный архитектурный конкурс на будущий региональный павильон, на который было представлено несколько проектов от местных гражданских инженеров и архитекторов. Победителем стал проект инженера Д.С. Лебедева - павильон в 150 квадратных сажен, в плане напоминающий букву П, внутренний двор которого должен был быть засеян дальневосточными культурами. Графических материалов, к сожалению, не сохранилось, однако в специализированной газете Дальневосточного выставочного комитета имеется описание победившего в конкурсе проекта: «в центре фасада - хребет-тоннель, с проложенным полотном железной дороги (дековилькой ${ }^{1}$ ) и подвижным составом (вагонетками), находящимися в действии. Чтобы попасть в павильон, посетитель должен сесть в вагон, проехать тёмный тоннель и выехать на открытую площадку, окружённую внутренними стенами павильона, с обычной фасадной разработкой и выходящими на площадку окнами и дверьми. При выезде из тоннеля, по прямой на противоположной стене открывается перспективная панорама Дальнего Востока с Тихим океаном, освещёнными яркими лучами взошедшего солнца. При входе в тоннель на фронтоне его горит надпись "к Великому океану"» [6, с. 65].

Однако главный выставочный комитет выставки и Московское архитектурное общество не отнеслись к проекту Д.С. Лебедева всерьёз, передав работу по разработке павильона известному московскому архитектору И.А. Голосову (на выставке 1923 года, как, впрочем, и на выставках 1937, 1939 и 1954 годов большинство региональных павильонов выполнялись именно столичными архитекторами, местные специалисты к этой работе не привлекались). Тем не менее И.А. Голосов, наверняка ознакомленный с предложением «Дальвысткома», поддержал предложение Д.С. Лебедева и продолжил его романтическую идею «продвижения от Байкала к Великому Океану» [7, с. 16]. Массивный основной объём павильона, снабжённый мачтой с надутыми парусами, будто проплывал мимо остальных сооружений (рис. 2, 3). В комплекс построек Дальневосточного отдела также входили

${ }^{1}$ Дековилька - [По имени изобретателя такой железной дороги, французского инженера Decauville] вагонетка переносной железной дороги на лесных промыслах, в горном деле и др. (Большой словарь иностранныхслов / ред. И.С. Пигулевская. - М. : Центрополиграф, 2008. - 688 с.). 
поставленные в ряд два шатра, повторявшие мотивы архитектуры жилищ коренных народностей Дальнего Востока, ярусная пагода-мачта и особо популярные среди посетителей выставки Китайские ворота (рис. 4). Все эти строения разных масштабов и ориентальных мотивов и стилей были уравновешены строгой геометрической композицией, свойственной ранним проектам И.А. Голосова [8, с. 46-47].

Следующая крупная всесоюзная выставка должна была состояться в 1937 году в честь 20-летнего юбилея Октябрьской революции. Её общественно-политическое значение было особенно велико. Помимо пропаганды успехов сельского хозяйства, Всесоюзная сельскохозяйственная выставка (ВСХВ) должна была стать ещё и «полигоном, на котором предстояло опробовать ... пути дальнейшего развития советской архитектуры и массового искусства» [9, с. 44]. Однако соавтор И.А. Голосова по проекту 1923 года - И.А. Француз, назначенный главным архитектором нового дальневосточного павильона, пошёл по пути, намеченному архитекторами ещё 14 лет назад. Павильон в его исполнении представлял собой смесь разных стилей, но восточные мотивы в архитектуре

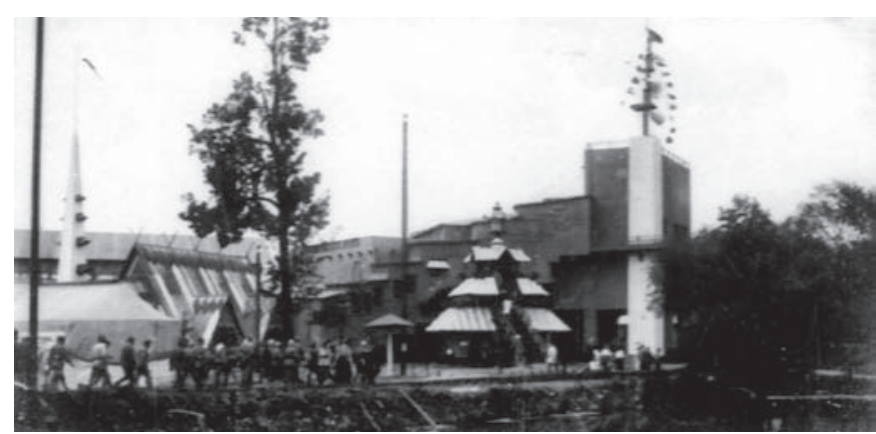

Рис. 2. Павильон Дальне-Восточной области. Архитекторы И.А. Голосов и И.А. Француз. 1923 год (источник: Фото-отдел архива Музея архитектуры имени Щусева. Ед. хранения MPA 10766)

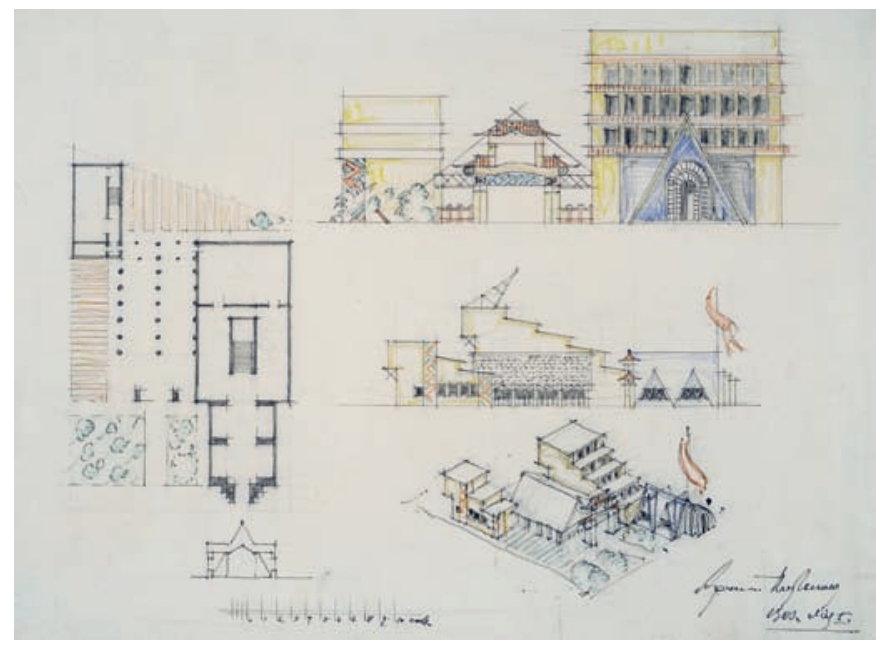

Рис. 3. Проект павильона Дальне-Восточной области. Архитекторы И.А. Голосов и И.А. Француз. 1923 год (источник: Графический отдел архива Музея архитектуры имени Щусева. ЕО. хранения PIA 5043) здания были доминирующими: центром композиции стал восьмиугольный угловой объём, завершённый конусообразным высоким шатром, напоминающим пагоды бурятских дацанов, а с площадью Колхозов его должен был соединять горбатый красно-золотой мостик, будто перенесённый из Китайских ворот павильона 1923 года (рис 5).

Между тем, помимо смены курса в архитектуре и градостроительстве Советского Союза, в 1930-е годы изменилась и политика партии в отношении Дальневосточного региона. В 1932 году недружественная СССР Японская империя захватила северный Китай и тем самым вышла непосредственно к границам советского Дальнего Востока. Опасность реальной войны, а также малонаселённость региона выдвигали новые задачи в отношении Дальневосточного края². Наиболее лако-

2 Дальневосточный край (или ДВК) - административно-территориальная единица с центром в Хабаровске, образованная в 1926 году на месте Дальневосточной области и просуществовавшая до 1938 года (Пикалов Ю.В. Административное устройство Дальнего Востока России В XIX-XX веках. Проблема критериев // Вестник ДВГСГА. Серия 1. Гуманитарные науки. 2008. - №1. - C. 62).

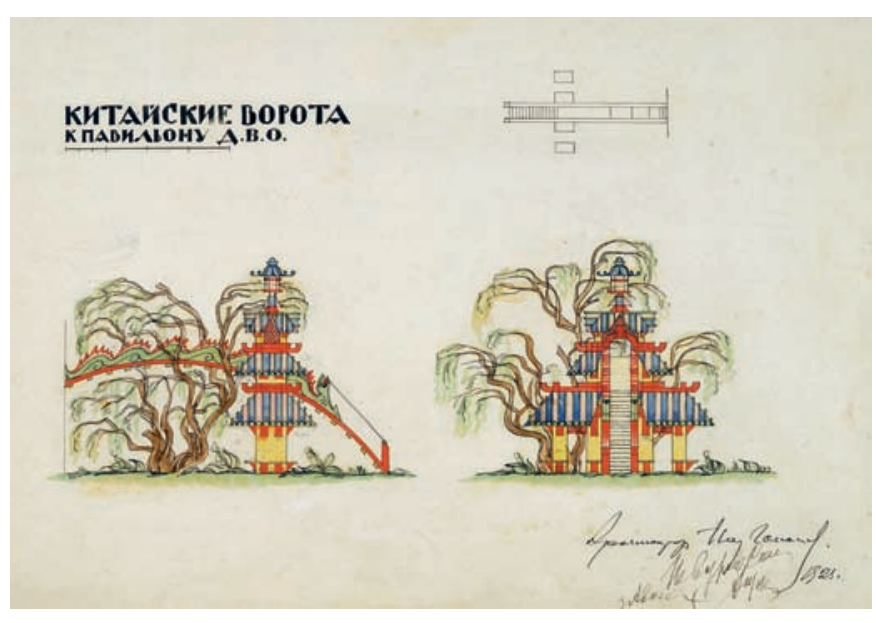

Рис. 4. Проект китайских ворот у павильона Дальне-Восточной области. Архитектор И.А. Голосов. 1923 год (источник: Графический отдел архива Музея архитектуры имени Щусева. ЕО. хранения PIA 4970)

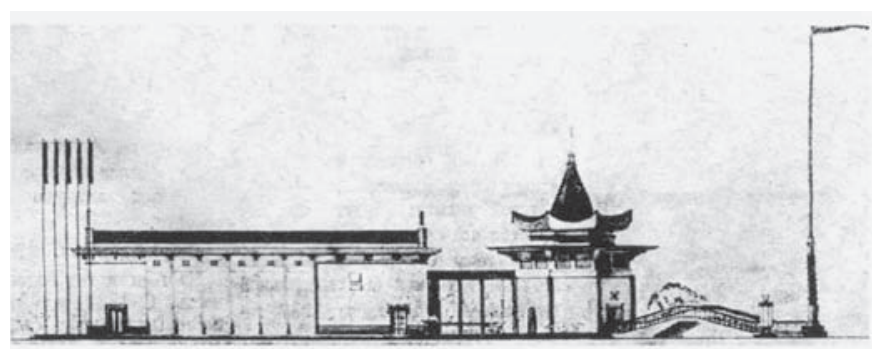

Рис. 5. Проект павильона Дальневосточного края. Архитектор И.А. Француз. 1937 год (источник: [9, с. 41]) 
нично они выразились в словах председателя Совета народных комиссаров СССР В.М. Молотова (размещённых впоследствии в главном зале павильона 1939-1954 годов): «Дальневосточный край мы рассматриваем как требующий всемерного дальнейшего укрепления мощный форпост советской власти на Востоке» [10, с. 3]. Выбранный И.А. Французом в попытке найти национальный по форме, но социалистический по содержанию романтический образ Дальнего Востока как «собственной» Азии уже не совпадал со стратегией власти. В ходе дискуссий об архитектурно-художественном оформлении выставки 1937 года, закончившихся её разгромом, павильон ДВК стал одной из главных мишеней критики, примером, в котором, по словам недавно назначенного главным архитектором ВСХВ А.Ф. Жукова ${ }^{3}$, «мотивы национальных черт применены неудачно и не по адресу» ${ }^{4}$. В октябре 1938 года на совещании, посвящённом архитектурно-художественному оформлению новой выставки, он же прямо указывал на невозможность использования на-

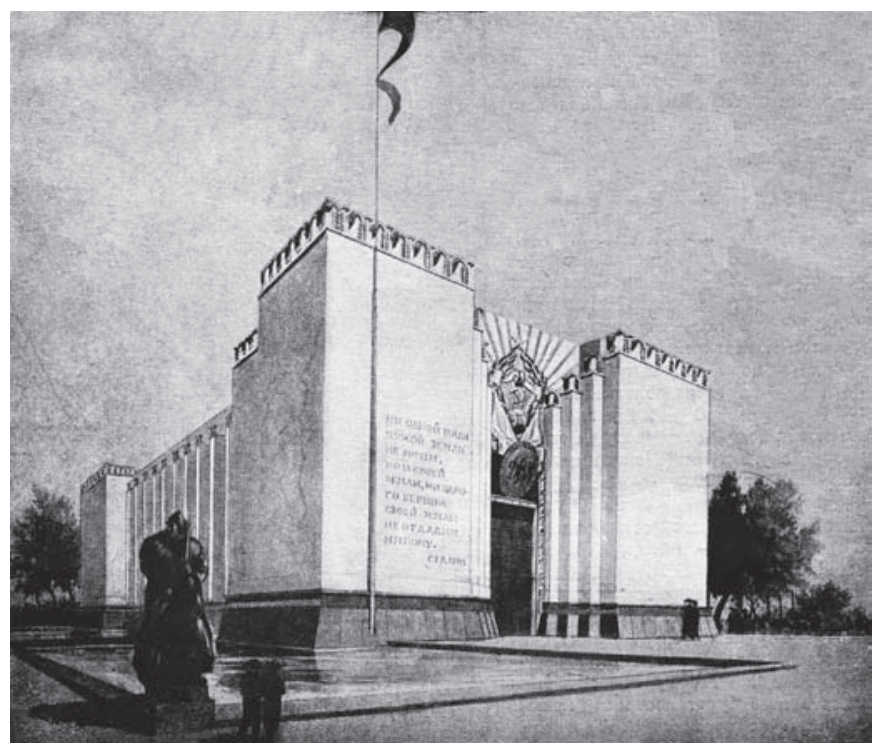

Рис. 6. Проект павильона Дальнего Востока. Архитекторы А.Ф. Жуков и С.Б. Знаменский. 1939 год (источник: «Архитектура (ССР», 1939 № 2, с. 24)

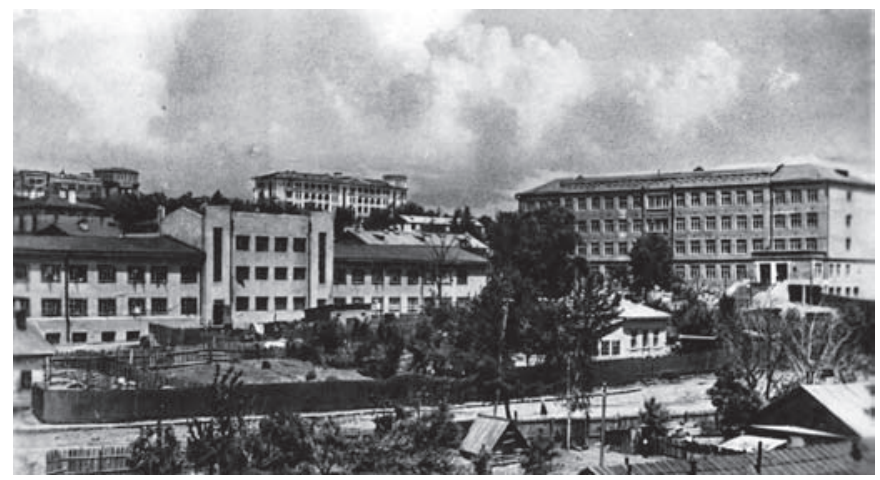

Рис. 7. Застройка Хабаровска. 1938 год (источник: Союзфото, фотография С. Образцова) циональных элементов в отношении здания: «павильон ДВК был решён в характере японо-монгольском, в то время когда всем известно, что это является коренным русским краем» 5 . Главному архитектуру выставки вторили и печатные издания, называющие павильон авторства И.А. Француза «буддийским храмом» [11, с. 110-111]. Изначально критиковалось и неуместное расположение павильона на генеральном плане ${ }^{6}$. Однако впоследствии близость его к Главному павильону и павильону Узбекской ССР объяснялась символом «грандиозности, бескрайности нашей страны, протянувшейся от «финских хладных скал» до Тихого Океана» [12, с. 13]. Перемены в экстерьере павильона оказались значительными: внешний его облик лишился всяких намёков на «азиатскость», стал полностью отвечать вышеуказанной доктрине форпоста СССР на Востоке (рис 6). Оставшись в границах демонтированного павильона 1937 года, новое сооружение увеличилось на несколько метров в высоту, стены лишились декора, только лишь фрагмент бокового фасада был украшен десятью фресками, изображающими природу Дальнего Востока - элемент, сохранившийся от предыдущего здания. По периметру стены павильона завершались выступами, напоминающими одновременно и зубцы кремлёвских стен, и колосья пшеницы. Образ «закованной в броню неприступной крепости» [10, с. 3] дополнялся гигантской скульптурой пограничника (скульптор П.А. Баландин) близ павильона со стороны площади Колхозов, а суровость и монументальность «дальневосточной крепости» ещё сильнее подчёркивались на контрасте с грациозностью и богатой отделкой соседнего павильона Узбекской ССР авторства С.Н. Полупанова. В профессиональной среде величественный павильон, впрочем, также подвергался критике. Например, архитектор Ю. Александер в своей статье 1939 года называл его излишне «грузным», расположенным своим второстепенным фасадом к площади Колхозов «вовсе неудачно» $[13$, с. 16]. Тем не менее найденный на ВСХВ образ здания, выражающий в своей архитектуре отношение власти к Дальнему Востоку как к «мощному форпосту» в Азии, как нельзя лучше иллюстрировал изменения, наступившие в регионе: к концу 1930-х годов здесь появились новые крупные центры промышленности, в том числе оборонной, важнейшие города получили утверждённые генеральные планы, и в некогда небольших, по преимуществу деревянных, уездных городах на окраине страны начали возводиться крупные монументальные здания в духе эпохи, заметно контрастирующие с фоновой малоэтажной застройкой (рис. 7).

${ }^{3}$ А.Ф. Жуков совместно С С.Б. Знаменским также стал и автором реконструкции здания Дальневосточного павильона на выставках 1939 и 1954 годов.

${ }_{4}^{4}$ РГАЭ. Фонд 7857, 0пись 1, Дело 59. «Стенограммы совещаний по вопросам архитектурно и скульпторов, о художественном оформлении павильонов, о показателях, о пропаганде на ВСХВ», С. 4.

${ }^{5}$ Там же.

${ }^{6}$ Н.В. Цицин на том же совещании по архитектурно-художественному оформлению ВСХВ в октябре 1938 года обращал внимание на то, что в расположении павильона ДВК между павильонами Узбекской ССР и Ленинграда «нет никакой увязки» (РГАЭ. Ф. 7857. 0п. 1. Д. 59. Л. 82). 
Изменения произошли не только во внешнем облике, но и в интерьере павильона «Дальний Восток»: если экстерьер отвечал за «оборонительную» составляющую в «теме единения труда с обороной» [14, с. 36], то интерьер был призван максимально раскрыть тему труда. Семь залов павильона, представляющих восемь областей края, были богато украшены живописью и монументальной скульптурой, над которыми трудились лучшие художники своего времени: А.А. Дейнека, Ю.И. Пименов, Г.Г. Нисский, В.А. Васильев, Е.С. Зернова. Их главной задачей было наглядно показать всему СССР те изменения, которые произошли с регионом за годы советской власти, отразить «неисчислимые богатства недр земли, тайги, морей и рек этого замечательного края» [15, с. 4], а также побудить крестьянское население отправиться осваивать восточные приграничные районы СССР. В этих целях при павильоне был организован даже специальный справочноконсультационный отдел по переселению трудящихся в этот «богатейший край нашей Родины» [16, с. 46]. Примечательно, что этот призыв в первую очередь относился к густонаселённым Украинской и Белорусской республикам, которые традиционно были основными «донорами» для Дальнего Востока ещё в предреволюционный период. Закреплённый за ДВК на выставке 1939 года статус «коренного русского края» также подразумевал под собой подчинённое положение местных народностей. Если в предыдущие годы национальное разнообразие региона всячески подчёркивалось, в том числе и посредством архитектуры, то с 1939 года главенствующая роль «титульной нации» стала определяющей. Это выражалось в целом ряде фресок и панно выставочных залов (например, «Приём Бурят-Монгольской делегации членами ЦК ВКП(б) и Советского правительства 27 января 1936 года» А.А. Дейнеки) и в пропагандисткой печати. В них неоднократно подчёркивалось насколько «изменилось положение народностей, населяющих районы края, они приобщены к советской культуре. Неузнаваем стал весь, когда-то заброшенный, отсталый дикий край» [10, с. 12] и как нынешние «колхозники живут в светлых и просторных домах европейского типа» [15, с. 42].

С открытием в 1954 году обновлённой выставки, теперь демонстрировавшей не только сельскохозяйственные достижения, но и успехи всего народного хозяйства страны, восстановленной после Великой Отечественной войны, процесс укрепления монументального образа дальневосточной твердыни был продолжен. Хотя павильон ДВК был одним из немногих выставочных построек, не подвергнувшихся значительной переделке, главным комитетом ВСХВ в ходе обсуждения ремонтно-восстановительных работ всё же было предложено закончить замыслы, «неосуществлённые из-за недостатка времени в 1939 году» ${ }^{7}$. В результате, «крепость» павильона была надстроена ещё на один сегмент башни, достигнув высоты в 26 метров, а на боковых фасадах были

РГАЭ. Фонд 7857. 0п. 1. Д. 3776 «Протокол № 2 заседания Главного комитета ВСХВ о ходе ремонтно-восстановительных работ на ВСХВ и материалы к протоколу», с. 70. устроены дополнительные парапеты, увенчанные все теми же зубцами-колосьями (рис. 8).

В дальнейшем, с наступлением «оттепели» в СССР, смены социально-политического курса и характера архитектурной политики, пропагандистская роль ВСХВ (с 1959 года - ВДНХ) ежегодно снижалась. Государство находило иные способы для призыва заселять и укреплять малозаселённый край, Дальний Восток стал получать заметно больше средств на развитие промышленности, сельского хозяйства и строительства, жители региона получили значительные по сравнению с другими регионами страны льготы и надбавки к заработной плате [17], а с развитием сети железных дорог и появлением новых воздушных маршрутов самый дальний регион страны стал гораздо ближе и доступней. В 1959 году павильон Дальнего Востока также сменил своё название. 0н стал называться «Советская книга», затем «Советская печать», а с 1966 года здесь располагался выставочный зал павильона «Советская культура» [9, с. 231]. В 1977 году пожар полностью уничтожил здание монументального форпоста, который изначально был сконструирован в основном из дерева.

В результате, в дальневосточных павильонах на всесоюзных выставках 1920-х - 1950-х годов отразились не только изменения стилевых направлений советской архитектуры первых десятилетий, но и перемены в государственной политике в отношении Дальнего Востока. В первой четверти XX века этот регион едва ли воспринимался в сознании местного населения «коренным русским краем», его ещё только предстояло административно, географически и ментально интегрировать в состав России [18, с. 31]. В результате форсированной политики СССР в восточном направлении, планомерного заселения и укрепления региона, его архитектурный образ на выставках также менялся. В сочетании форм современных европейских стилей и «ориентальных мотивов» доля последних уменьшалась от года к году, окончательно исчезнув к 1950-м годам. Впрочем, архитекторы никогда не

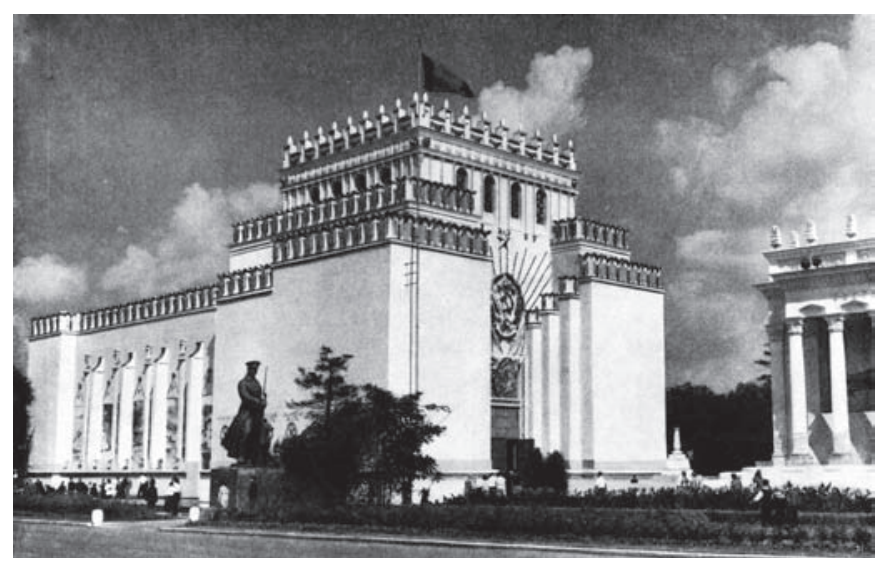

Рис. 8. Павильон Дальнего Востока на ВСХВ. Архитекторы А.Ф. Жуков и С.Б. Знаменский. 1954 год (источник: Жуков А.Ф. Архитектура Всесоюзной Сельскохозяйственной Выставки. - М. : Государственное Издательство Литературы по (тороительству и Архитектуре, 1955. - С. 66) 
отказывались от определённой символичности, связанной с романтизацией Дальнего Востока, его огромных размеров, природы, его самобытности как своей «Азиатской России» $[18$, с. 38]. Именно поэтому неизменным атрибутом всех павильонов ДВ на выставках оставался высокий флагшток с развевающимся знаменем - символом утверждения и нерушимости границ страны на Востоке.

\section{Лumepamypa}

1. Выставочные ансамбли СССР. 1920-1930-е годы. Материалы и документы / В.П. Толстой (отв. редактор) [и др.]. - М. : Галарт, 2006. - 468 с. - С. 3-8.

2. Крадин, Н.П. Старый Хабаровск. Портрет города в дереве и камне. 1858-2008 / Н.П. Крадин. - Хабаровск : Риотип, 2008. -448 c.

3. Базилевич, M.E. Деятельность и вклад выпускников Санкт-Петербургских архитектурных и инженерных школ в развитие архитектуры Дальнего Востока. Вторая половина XIX - начало XX вв. : дисс. ... канд. арх. : 18.00.01 / М.E. Базилевич. - СПб, 2018.

4. Съезды Советов РСФСР в постановлениях и резолюциях : Сборник документов / М. : Издательство Ведомостей Верховного Совета РСФСР, 1939. - XII. - 540 с.

5. Щусев, А.В. К конкурсу проектов планировки сельскохозяйственной выставки / А.В. Щусев // Архитектура. - 1923. - № 1-2.

6. Хроника. Из жизни Главного Выставочного Комитета // Всероссийская сельско-хозяйственная кустарно-промышленная выставка. Известия Дальне-Восточного выставочного комитета. - 1923. - № 2 (1 мая). - С. 63-66.

7. Рязанцев, И. Искусство советского выставочного ансамбля, 1917-1970 / В.И. Рязанцев. - М. : Советский художник, 1976.

8. Хан-Магомедов, С.О. Илья Голосов / С.О. Хан-Магомедов. - М. : Стройиздат, 1988. - 232 с.

9. Зиновьев, А.Н. Ансамбль ВСХВ: архитектура и строительство / А.Н. Зиновьев. - М., 2014. - 408 с.

10. Самарин, Г., Антонович, В. Павильон «Дальний Восток» : путеводитель / Г. Самарин, В. Антонович. - М. : Сельхозгиз, 1940.

11. Белинцева, И.В. Ансамбль Всесоюзной сельскохозяйственной выставки в контексте истории советской архитектуры 1930-х гг. : дисс. ... канд. искусствоведения. : 18.00.01 / И.В. Белинцева. - Москва, 1989.

12. Корнфельд, Я. Архитектура выставки / Я. Корнфельд // Архитектура СССР. - 1939. - № 9. - С. 4-29.

13. Александер, Ю. Площадь Колхозов / Ю. Александер // Строительство Москвы. - 1939. - № 15. - С. 14-21.

14. Орлова, М. Скульптура и живопись на Всесоюзной сельскохозяйственной выставке / М. Орлова, К. Ситник // Архитектура СССР. - 1939. - № 9. - С. 30-40.

15. Ладыгин, И. Павильон «Дальний Восток» : путеводитель / М. : Сельхозгиз, 1939.
16. Севастьянов, Г.А. Хабаровский край на Всесоюзной сельскохозяйственной выставке 1954 года / Хабаровск : Хабаровское книжное издательство, 1954.

17. Мотрич, Е.Л. Государственная политика хозяйственного освоения и заселения Дальнего Востока с конца XIX века до середины 1980-х годов / Е.Л. Мотрич, С.А. Кравчук // Вестник ДВО РАН. - 2006. - № 6. - С. 120-128.

18. Ремнёв, А.В. Россия Дальнего Востока. Имперская география власти XIX - начала XX веков / А.В. Ремнев. - Омск : Изд-во Омск. гос. ун-та, 2004. - 552 с.

\section{References}

1. Tolstoy V.P. (ed.) [et al.] Vystavochnye ansambli SSSR. 1920-1930-e gody. Materialy i dokumenty [Exhibition ensembles in the USSR. 1920-s - 1930-s. Materials and documents]. Moscow, Galart Publ., 2006, 468 p., pp. 3-8.

2. Kradin, N.P. Staryi Khabarovsk. Portret goroda v dereve $i$ kamne. 1858-2008. [Old Khabarovsk. Portrait of the city in wood and stone. 1858-2008]. Khabarovsk, Riotip Publ., 2008, 448 p.

3. Bazilevich, M.E. Deyatel'nost' i vklad vypusknikov SanktPeterburgskikh arkhitekturnykh i inzhenernykh shkol v razvitie arkhitektury Dal'nego Vostoka. Vtoraya polovina XIX - nachalo XX vv. : diss. ... kand. arkh. [The practice and contribution of graduates of St. Petersburg architectural and engineering schools to the development of architecture in the Far East. The second half of the XIX - beginning of XX centuries. PhD. Architecture diss.]. Saint Petersburg, 2018.

4. S"ezdy Sovetov RSFSR v postanovleniyakh i rezolyutsiyakh : Sbornik dokumentov. [Congresses of Soviets of the RSFSR in resolutions. Collection of documents]. Moscow, 1939, $540 \mathrm{p}$.

5. Shchusev, A.V. K konkursu proektov planirovki sel'skokhozyaistvennoi vystavki [Competition of planning designs for the agricultural exhibition]. In: Arkhitektura [Architecture], 1923, no. 1-2.

6. Khronika. Iz zhizni Glavnogo Vystavochnogo Komiteta [The Chronicle. From the life of the Main Exhibition Committee]. In: Vserossiiskaya sel'sko-khozyaistvennaya kustarno-promyshlennaya vystavka. Izvestiya Dal'ne-Vostochnogo vystavochnogo komiteta [All-Russian Agricultural Handicraft and Industrial Exhibition. News of the Far Eastern Exhibition Committee], 1923, no. 2, pp. 63-66.

7. Ryazantsev, I. Iskusstvo sovetskogo vystavochnogo ansamblya, 1917-1970 [Art of the Soviet exhibition ensemble, 1917-1970]. Moscow, 1976.

8. Khan-Magomedov, S.0. Il'ya Golosov. Moscow, Stroiizdat Publ., 1988, 232 p.

9. Zinov'ev, A.N. Ansambl' VSKhV: arkhitektura i stroitel'stvo [The All-Union Agricultural Exhibition Ensemble: Architecture and Construction]. Moscow, 2014, 408 p.

10. Samarin, G., Antonovich, V. Pavil'on «Dal'nii Vostok»: putevoditel' [The All-Union Agricultural Exhibition Ensemble: Architecture and Construction]. Moscow, 2014, 408 p. 
11. Belintseva, I.V. Ansambl' Vsesoyuznoi sel'skokhozyaistvennoi vystavki v kontekste istorii sovetskoi arkhitektury 1930-kh gg. : diss. ... kand. iskusstvovedeniya. [The ensemble of the All-Union Agricultural Exhibition in the context of the history of Soviet architecture of the 1930-s. PhD. History of Art diss.]. Moscow, 1989.

12. Kornfel'd, Ya. Arkhitektura vystavki [Architecture of the exhibition]. In: Arkhitektura SSSR [Architecture of the USSR], 1939, no. 9, pp. 4-29.

13. Aleksander, Yu. Ploshchad' Kolkhozov [The Square of Kolkhozes]. In: Stroitel'stvo Moskvy [Moscow Construction], 1939, no. 15 , pp. $14-21$.

14. Orlova M., Sitnik K. Skul'ptura i zhivopis' na Vsesoyuznoi sel'skokhozyaistvennoi vystavke [Sculpture and painting at the All-Union Agricultural Exhibition]. In: Arkhitektura SSSR [Architecture of the USSR], 1939, no. 9, pp. 30-40.
15. Ladygin, I. Pavil'on «Dal'nii Vostok» : putevoditel' [Far Eastern Pavilion : a guide]. Moscow, Selkhozgiz Publ., 1939.

16. Sevast'yanov, G.A. Khabarovskii krai na Vsesoyuznoi sel'skokhozyaistvennoi vystavke 1954 goda [Khabarovsk Territory at the 1954 All-Union Agricultural Exhibition]. Khabarovsk, Khabarovsk book publishing house ,1954.

17. Motrich E.L., Kravchuk S.A. Gosudarstvennaya politika khozyaistvennogo osvoeniya i zaseleniya Dal'nego Vostoka s kontsa XIX veka do serediny 1980-kh godov [The state policy of economic development and settlement of the Far East from the end of the 19th century to the mid-1980-s]. In: Vestnik DVO RAN, 2006, no. 6, pp. 120-128.

18. Remnev A.V. Rossiya Dal'nego Vostoka. Imperskaya geografiya vlasti XIX - nachala XX vekov [Russia of the Far East. Imperial geography of power of the XIX - early XX centuries]. 0msk, 2004, 552 p.

Степанов Кирилл Константинович (Москва). Аспирант, научный сотрудник Научно-исследовательского института теории и истории архитектуры и градостроительства (филиал ФГБУ «ЦНИИП Минстроя России»). Эл.почта: stepanovkk@gmail.com.

Stepanov Kirill K. (Moscow). Postgraduate student and research fellow of the the Research Institute of Theory and History of Architecture and Urban Planning (9 Dushinskaya st, Moscow, 111024. NIITIAG), branch of the Central Institute for Research and Design of the Ministry of Construction and Housing and Communal Services of the Russian Federation (TsNIIP). E-mail: stepanovkk@gmail.com. 